\title{
Glyphosate for Weed Control in Puerto Rican Pastures $^{1,2}$
}

\author{
Jaime González-Ibáñez ${ }^{3}$ \\ ABSTRACT
}

Glyphosate [n-(phosphonomethyl) glycine] at $1 \%, 1.5 \%$, and $2 \% \mathrm{v} / \mathrm{v}$ effectively controlled Paspalum virgatum, Sporobolus poiretti, Paspalum conjugatum, and Sida rhombifolia in pastureland in four separate locations. Effective control was also achieved with a roller applicator and a Walk-a-wick applicator at concentrations of $14.3 \%, 20 \%$, and $33 \% \mathrm{v} / \mathrm{v}$. There was no harmful effect on the pastures when Glyphosate was applied as a directed spray.

\section{INTRODUCTION}

Cortaderagrass (Paspalum virgatum L.), also known as swordgrass and razorgrass, and cortadora (Paspalum millegrana Schrad.) are two perennial bunchy grasses common in pastures, perennial crops and on roadsides of Puerto Rico. Leaves of cortaderagrass are erect and have toothed, razor sharp margins (1). Smutgrass (Sporobolus poiretti Hitch.), an aggressive perennial grass which grows from $30 \mathrm{~cm}$ to 1 meter high, also invades introduced and native pastures in Puerto Rico (4).

Our pasturelands are often invaded by such tall, undesirable grasses. The grasses are either unpalatable to cattle or are eaten only when succulent and tender. Cortaderagrass is considered by Cárdenas as a highly noxious weed (1). One method of control of such grasses, developed by the Agricultural Experiment Station, has been to cut the stumps at ground level and to dust them either Chlorea or Ureabor herbicides (2). In the case of broadleaf weeds, effective control has been achieved with the use of picloram or Dicamba and 2,4-D (5). Glyphosate ${ }^{4}$ effectively controlled Venezuela grass (Paspalum fasciculatum), a widely disseminated weed on the Island that poses a serious problem to the dairy industry. Hexazinone and Karbutilate have also shown great potential

${ }^{1}$ Manuscript submitted to Editorial Board August 22, 1983.

${ }^{2}$ This paper covers research conducted cooperatively by the Monsanto Chemical Company and the College of Agricultural Sciences (Rio Piedras Center), partially funded by the Monsanto Chemical Company under a Memorandum of Agreement, State Department. Registry No. EEA 81-82-93.

${ }^{3}$ Associate Biologist, College of Agricultural Sciences (Río Piedras Center). The author wishes to thank Dr. Victor M. Urrutia for his participation in the fieldwork. Also he thanks Mr. Rafael Valentín from Barceloneta, Mr. José Cordero from Camuy, and Mr. Joaquin Mouliert from Fajardo on whose pasturelands this work was conducted.

${ }^{4}$ Trade names in this publication are used only to provide specific information. Mention of a trade name does not constitute a warranty of equipment or materials by the Agricultural Experiment Station of the University of Puerto Rico, nor is this mention a statement of preference over other equipment or materials. 
for controlling the Venezuela weed (3). Extensive research on grassland management has been conducted in Puerto Rico (6), but few data are available on the use of herbicides to help maintain the stands of pasture grasses. Glyphosate may be approved as a postemergent herbicide for spot treatment of the grasses cortadera, smut, sour paspalum, and arrowleaf sida in Puerto Rico, if specific tests are conducted, as required by recent federal regulations. For this purpose seven experiments were conducted in four pasture areas located in Barceloneta, Gurabo, Camuy, and Fajardo, with a high infestation of the aforementioned weeds, to test the efficacy of Glyphosate. A possible 24(c) registration of Glyphosate as spot treatment in pastures could be obtained with the data generated from this investigation.

\section{MATERIALS AND METHODS}

For best control, Glyphosate must be applied as a directed spot treatment to the weeds, regardless of formulation employed. Three methods of application and seven concentrations of Glyphosate were investigated. Application methods were: 1) use of a $\mathrm{CO}_{2}$ cylinder, scuba-type back pack, with a two-stage regulator and spray tank; 2) a roller applicator that swipes herbicide directly onto tall weeds (sideswipe); and 3) a wick applicator which sponges herbicide from inside a plastic pipe (Walk-awick). The seven concentrations tested were $0.5 \%, 1 \%, 1.5 \%, 2 \%, 14.3 \%$, $20 \%$, and $33 \% \mathrm{v} / \mathrm{v}$.

\section{EXPERIMENT NO. 1}

For the first experiment, a stargrass (Cynodon nlemfuensis) pastureland heavily infested with patches of cortaderagrass, was selected in Barceloneta. The patches averaged four plants per plot, each 1 square meter. Experimental design was a randomized block arrangement. Herbicide plots were $4 \mathrm{~m}$ by $8 \mathrm{~m}$ and replicated three times. Glyphosate was evaluated at the 5 concentrations (v/v) of $0,0.5 \%, 1 \%, 1.5 \%$, and $2 \%$ applied by spraying the entire weed with a $\mathrm{CO}_{2}$ tank plot sprayer through a single solid-cone nozzle at a rate of 1 liter $/ \mathrm{min}$ at a constant pressure of $25 \mathrm{p} / \mathrm{in}^{2}$. Date of application was June 18, 1982.

Weed control evaluations were made on the basis that $100=$ all weeds controlled and $0=$ no control. Pasture stand evaluation was made on the basis that $0=$ no stand and $100=$ perfect stand. Two persons rated visually the injury shown by the cortaderagrass after 30 days (early control) and 140 days (full control). A final evaluation of the pasture stand was made at the end of the test.

\section{EXPERIMENT NO. 2}

For the second experiment, another stargrass pastureland invaded by cortadera was selected. In addition to cortaderagrass, the pasture con- 
tained smutgrass and sourgrass (Trichachne insularis). Herbicidal plots were $4 \mathrm{~m}$ by $6 \mathrm{~m}$ replicated three times. Treatments tested were Glyphosate sprayed with the $\mathrm{CO}_{2}$ tank sprayer at concentrations (v/v) of 0 , $0.5 \%, 1 \%, 1.5 \%$, and $2 \%$, and applied with both sideswipes and Walk-awick at $33 \%$ concentration, making a total of seven treatments. Evaluations of the weed injury were made at 30 days (early control) and at 140 days (full control) after treatment with the herbicide. Also evaluations of the pasture stands were made at the beginning and at the end of the experiment.

\section{EXPERIMENT NO. 3}

A third experiment was conducted in a mixed pasture made up of Guinea grass (Panicum maximum L.) and stargrass heavily infested with cortaderagrass and arrowleaf sida (Sida rhombifolia L.). Fifteen $4 \mathrm{~m} \times 4$ $\mathrm{m}$ plots were used to make a randomized block design with five treatments and three replications. The five treatments were 33, 20, 14.3\% (swiped with the roller), $33 \% \mathrm{v} / \mathrm{v}$ (applied with the Walk-a-wick), and an untreated check. Evaluations of the weeds were made at the beginning and at the end of the experiment to determine early and full control, respectively. Also an evaluation of the pasture stand was taken at the beginning and at the end of the experiment. Table 1 shows dates of herbicide application and soil characteristics at the test sites.

\section{EXPERIMENT NO. 4}

This experiment was conducted on a pastureland at the Gurabo Substation. The pasture herbage was a mixture of guinea grass, pangola grass and native grass heavily infested with 1 - to $4-\mathrm{m}^{2}$ patches of cortaderagrass in the flowering stage, $1.5 \mathrm{~m}$ tall. There were several patches from 1 to 4 $\mathrm{m}^{2}$ of this grass. Plots were laid allowing at least one of these patches per replication. The herbicide Glyphosate was applied over the patches as a directed spray at $0.5,1,1.5$, and $2 \% \mathrm{v} / \mathrm{v}$ concentrations. Evaluations of both weed condition and pasture stands were made at the beginning and at the end of the experiment. Evaluations on pasture stands also were performed at the beginning and at the end of the experiment.

\section{EXPERIMENTS NO. 5 AND 6}

Experiments 5 in Camuy and 6 in Fajardo were conducted to test 5 concentrations of Glyphosate for control of smutgrass and sour paspalum, respectively. Both experiments were conducted on a cattle ranch. The herbicide was applied to $2 \mathrm{~m}$ by $2 \mathrm{~m}$ plots in a randomized block arrangement. The concentrations tested were $0,0.5,1,1.5$, and $2 \% \mathrm{v} / \mathrm{v}$.

Visual ratings by two persons were used to estimate the smutgrass injury or the sour paspalum injury, respectively. Ratings were performed 
TABLE 1.-Date of postemergence applications of Glyphosate and soil characteristics (6) for pasture experiments at Barceloneta, Gurabo, Fajardo and Camuy, Puerto Rico

\begin{tabular}{|c|c|c|c|c|c|c|c|c|}
\hline \multirow{3}{*}{ Experiment } & \multirow{3}{*}{ Location } & \multirow{3}{*}{$\begin{array}{c}\text { Treatment } \\
\text { data }\end{array}$} & \multirow{3}{*}{$\begin{array}{l}\text { Soil } \\
\text { type } \\
\text { order }\end{array}$} & \multicolumn{5}{|c|}{ Chemical and physical properties } \\
\hline & & & & \multirow{2}{*}{$\mathrm{pH}$} & \multirow{2}{*}{$\begin{array}{l}\text { Percent } \\
\text { of } \\
\text { organic } \\
\text { matter }\end{array}$} & \multicolumn{3}{|c|}{ Soil composition (\%) } \\
\hline & & & & & & Sand & Clay & Silt \\
\hline 1. Stargrass & Barceloneta & June 18, 1982 & Oxisol & 5.55 & 0.39 & 88.0 & 8.80 & 3.20 \\
\hline 2. Stargrass & Barceloneta & June 19, 1982 & Oxisol & 5.55 & 0.39 & 88.0 & 8.80 & 3.20 \\
\hline 3. Stargrass & Barceloneta & June 21, 1982 & Oxisol & 5.55 & 0.39 & 88.0 & 8.80 & 3.20 \\
\hline 4. Mixed grass & Gurabo & June 23,1982 & Inceptisol & 6.6 & 4.90 & 22.7 & 36.00 & 40.70 \\
\hline 5. Smutgrass & Fajardo & June 24, 1982 & Inceptisol & 8.2 & 1.66 & 22.0 & 61.60 & 16.40 \\
\hline 6. Sourpaspalum & Fajardo & June 24, 1982 & Inceptisol & 8.2 & 1.66 & 22.0 & 61.00 & 16.40 \\
\hline 7. Smutgrass & Camuy & June 25,1982 & Ultisol & 7.39 & 3.01 & 42.0 & 37.6 & 20.4 \\
\hline
\end{tabular}


at 30 days for early control and at 140 days for full control, after treatment.

\section{EXPERIMENT NO. 7}

Experiment 7 in Fajardo was conducted in a guineagrass pasture established 3 years previously that had been invaded by smutgrass and showed 10 plants of this weed per square meter.

The experimental design was randomized blocks. The herbicide concentrations tested were $0,0.5,1,1.5$, and $2 \% \mathrm{v} / \mathrm{v}$ applied with the $\mathrm{CO}_{2}$ plot sprayer at a constant pressure of $25 \mathrm{lb} / \mathrm{in}^{2}$ and calibrated to deliver

TABLE 2.-Cortaderagrass control at 30 and 140 days afte Glyphosate application and average stargrass pasture stand at the beginning and at the end of experiment at

Barceloneta. Experiment 1

\begin{tabular}{|c|c|c|c|c|c|}
\hline \multirow{2}{*}{$\begin{array}{l}\text { Herbicide } \\
\text { treatment }\end{array}$} & \multirow{2}{*}{$\begin{array}{c}\text { Percent } \\
\text { Glyphosate used }\end{array}$} & \multicolumn{2}{|c|}{ Cortaderagrass control } & \multicolumn{2}{|c|}{ Average pasture stand } \\
\hline & & 30 days & 140 days & 0 days & 140 days \\
\hline 1. Glyphosate & 0.5 & $94.3 \mathrm{a}^{1,2}$ & $94.3 \mathrm{a}$ & $78.33 \mathrm{a}^{3}$ & $100 \mathrm{a}$ \\
\hline 2. Glyphosate & 1.00 & $98 \mathrm{a}$ & $98 \mathrm{a}$ & $68,33 \mathrm{a}$ & $100 \mathrm{a}$ \\
\hline 3. Glyphosate & 1.50 & $100 \mathrm{a}$ & $100 \mathrm{a}$ & $78.33 \mathrm{a}$ & $100 \mathrm{a}$ \\
\hline 4. Glyphosate & 2.00 & $100 \mathrm{a}$ & $100 \mathrm{a}$ & $70.30 \mathrm{a}$ & $100 \mathrm{a}$ \\
\hline 5. Check & - & $0 \mathrm{~b}$ & $0 \mathrm{~b}$ & $80.00 \mathrm{a}$ & $60 \mathrm{a}$ \\
\hline
\end{tabular}

${ }^{1}$ Results recorded as visual estimates 30 and 140 days after the application of Glyphosate.

Each estimate is a value averaged from three plots and agreed upon by two observers.

${ }^{2}$ Values in the same column with the same letter do not differ significantly (P .05)

${ }^{3}$ Results recorded as visual estimates at the beginning and at the end of the experiment.

$380 \mathrm{l} / \mathrm{ha}$ and $33 \% \mathrm{v} / \mathrm{v}$ wiped over the smutgrass with a sideswipe. Herbicide plots were $2 \mathrm{~m}$ by $2 \mathrm{~m}$ and replicated three times.

Visual ratings by two persons were used to estimate smutgrass injury at 30 days and 140 days after the herbicide treatment.

All data were statistically analyzed and treatment means compared with Duncan's multiple range test.

\section{RESULTS AND DISCUSSION}

Undisturbed grass completely closed in at the void patches left by the total destruction of the weeds during the period following treatment with the herbicide (table 2). In the second and third experiments also, the cortaderagrass was killed and entirely replaced by stargrass plants from adjacent areas. Glyphosate application at the concentrations tested gave nearly perfect control of this weed, both when rated at 30 days after treatment and at the conclusion of the experiment (tables 3 and 4). Some regrowth was noticed at 140 days after treatment with $14.3 \%$ herbicide 
(v/v) applied with the sideswipe. Retreatment at 90 days may have been needed for the complete weed elimination with this procedure. Visual inspection indicated that none of the Glyphosate treatments adversely affected the stargrass. In fact, pasture herbage appeared to be in better condition in treated than in untreated check plots. This was probably due to the elimination of competition. This herbicide is excellent for

TABLE 3.-Cortaderagrass control at 30 and 140 days after Glyphosate application and average stargrass pasture at Barceloneta. Experiment 2

\begin{tabular}{|c|c|c|c|c|c|}
\hline \multirow{2}{*}{$\begin{array}{l}\text { Herbicide } \\
\text { treatment }\end{array}$} & \multirow{2}{*}{$\begin{array}{l}\text { Percent } \\
\text { Glyphosate } \\
\text { used }\end{array}$} & \multicolumn{2}{|c|}{ Cortaderagrass control } & \multicolumn{2}{|c|}{ Average pasture stand } \\
\hline & & 30 days & 140 days & 0 days & 140 days \\
\hline 1. Glyphosate & 0.5 & $97 \mathrm{a}^{1,2}$ & $97 \mathrm{a}$ & $70 a^{3}$ & $96 \mathrm{a}$ \\
\hline 2. Glyphosate & 1.00 & $97 \mathrm{a}$ & 97 a & 60 a & $98 \mathrm{a}$ \\
\hline 3. Glyphosate & 1.50 & $100 \mathrm{a}$ & $100 \mathrm{a}$ & $80 \mathrm{a}$ & $100 \mathrm{a}$ \\
\hline 4. Glyphosate & 2.00 & $100 \mathrm{a}$ & $100 \mathrm{a}$ & 75 a & $100 \mathrm{a}$ \\
\hline 5. Glyphosate (Walk-a-wick) & 33.00 & $100 \mathrm{a}$ & $100 \mathrm{a}$ & $75 \mathrm{a}$ & $100 \mathrm{a}$ \\
\hline 6. Glyphosate (Sideswipe) & 33.00 & $100 \mathrm{a}$ & $100 \mathrm{a}$ & $70 \mathrm{a}$ & $100 \mathrm{a}$ \\
\hline 7. Check & - & $0 \mathrm{~b}$ & $0 \mathrm{~b}$ & $70 \mathrm{a}$ & $60 \mathrm{a}$ \\
\hline
\end{tabular}

${ }^{1}$ Results recorded as visual estimates 30 and 140 days after the applications of Glyphosate. Each estimate is a value averaged from three plots and agreed upon by two observers.

${ }^{2}$ Values in the same column with the same letter do not differ significantly (P .05)

${ }^{3}$ Results recorded as visual estimates at the beginning and at the end of the experiment.

TABLE 4.-Cortaderagrass control at 30 and 140 days after Glyphosate application with sideswipe and walk-a-wick and stargrass pasture stand at the beginning and end of the experiment at Barceloneta. Experiment 3

\begin{tabular}{lcccccc}
\hline \multirow{2}{*}{$\begin{array}{c}\text { Herbicide } \\
\text { treatment }\end{array}$} & $\begin{array}{c}\text { Percent } \\
\text { Glyphosate } \\
\text { used }\end{array}$ & \multicolumn{2}{c}{$\begin{array}{c}\text { Cortaderagrass con- } \\
\text { trol }\end{array}$} & & \multicolumn{2}{c}{$\begin{array}{c}\text { Average pasture } \\
\text { stand }\end{array}$} \\
\cline { 3 - 4 } \cline { 6 - 7 } & 30 days & 140 days & & 0 days & 140 days \\
\hline 1. Glyphosate (Sideswipe) & 33 & $100 \mathrm{a}^{1,2}$ & $100 \mathrm{a}$ & & $66 \mathrm{a}^{3}$ & $100 \mathrm{a}$ \\
2. Glyphosate (Sideswipe) & 20 & $100 \mathrm{a}$ & $100 \mathrm{a}$ & & $55 \mathrm{a}$ & $100 \mathrm{a}$ \\
3. Glyphosate (Sideswipe) & 14.3 & $100 \mathrm{a}$ & $100 \mathrm{a}$ & & $53 \mathrm{a}$ & $100 \mathrm{a}$ \\
4. Glyphosate (Wick-a-wick) & 33 & $100 \mathrm{a}$ & $100 \mathrm{a}$ & & $43 \mathrm{a}$ & $100 \mathrm{a}$ \\
5. Check & - & $0 \mathrm{~b}$ & $0 \mathrm{~b}$ & & $43 \mathrm{a}$ & $50 \mathrm{a}$ \\
\hline
\end{tabular}

${ }^{1}$ Results recorded as visual estimates 30 and 140 days after treatment with Glyphosate. Each estimate is a value averaged from three plots and agreed upon by two observers.

${ }^{2}$ Values in the same column with the same letter do not differ significantly (P .05).

${ }^{3}$ Results recorded as visual estimates at the beginning and at the end of the experiment.

killing cortaderagrass, but must be applied as a spot treatment in pastures, where the dense plant population makes minimization of spray drift difficult.

There were no significant differences between Glyphosate concentrations for cortadera control. Also any concentration of Glyphosate of $20 \%$ $\mathrm{v} / \mathrm{v}$ or higher applied with the sideswipe was shown to be effective in controlling cortaderagrass throughout the growing season. 
Various patches of sourgrass (Trichachne insularis L. Hees) present in the test plots were also destroyed by these herbicide treatments, but the population of this weed was insufficient to warrant a rating of performance. Glyphosate applied with the sideswipe at either concentration also gave total destruction of arrowleaf sida and stink weed, but these weeds were not present in sufficient population to warrant rating either.

Excellent control of the cortadera was obtained with every herbicide treatment at Gurabo. There was a perfect stand at the conclusion of the experiment at any rate while untreated plots remained covered by the patches of weeds at 140 days after treatment (table 5). The target weed was controlled by the Glyphosate while the non-target mixture had closed in completely at 140 days after treatment.

TABLE 5.-Cortaderagrass control at 30 and 140 days after Glyphosate application and average pangola-guinea and native grass mixture at the beginning and at the end of the experiment at Gurabo Research Center. Experiment 4

\begin{tabular}{|c|c|c|c|c|c|}
\hline \multirow{2}{*}{$\begin{array}{l}\text { Herbicide } \\
\text { treatment }\end{array}$} & \multirow{2}{*}{$\begin{array}{l}\text { Percent } \\
\text { Glyphosate } \\
\text { used }\end{array}$} & \multicolumn{2}{|c|}{ Cortaderagrass control } & \multicolumn{2}{|c|}{ Average pasture stand } \\
\hline & & 30 days & 140 days & 0 days & 140 days \\
\hline 1. Glyphosate & 0.5 & $90.3 \mathrm{a}^{1,2}$ & $100 \mathrm{a}$ & $91 \mathrm{a}^{3}$ & $100 \mathrm{a}$ \\
\hline 2. Glyphosate & 1.00 & $98 \mathrm{a}$ & $100 \mathrm{a}$ & $70 \mathrm{a}$ & $100 \mathrm{a}$ \\
\hline 3. Glyphosate & 1.50 & $100 \mathrm{a}$ & $100 \mathrm{a}$ & $85 \mathrm{a}$ & $100 \mathrm{a}$ \\
\hline 4. Glyphosate & 2.00 & $100 \mathrm{a}$ & $100 \mathrm{a}$ & $79 a$ & $100 \mathrm{a}$ \\
\hline 5. Check & - & $0 \mathrm{~b}$ & $0 \mathrm{~b}$ & $90 \mathrm{a}$ & $90 \mathrm{a}$ \\
\hline
\end{tabular}

${ }^{1}$ Results recorded as visual estimates 30 and 140 days after the application of Glyphosate. Each estimate is a value averaged from three plots and agreed upon by two observers.

${ }^{2}$ Values in the same column with the same letter do not differ significantly (P .05)

${ }^{3}$ Results recorded as visual estimates at the beginning and at the end of the experiment.

Results at Fajardo demonstrated that smutgrass and sour paspalum can be controlled with Glyphosate at rates of $0.5 \% \mathrm{v} / \mathrm{v}$ or higher for up to 140 days. Results at Camuy demonstrate that smutgrass can be eliminated by a single application of Glyphosate at concentrations of $0.5 \% \mathrm{v} / \mathrm{v}$ or higher. There was a total cover of weeds in untreated check plots while a succession of tall guineagrass plants was rapidly growing and taking over the treated areas. Weed control was perfect in experiments 5, 6 and 7 when Glyphosate treatments were used while weeds in check plots were not controlled at all.

It appears that Glyphosate can be employed on pasturelands as a directed spray to control post-emergent cortaderagrass, smutgrass, sour paspalum and arrowleaf sida growth.

\section{RESUMEN}

El herbicida Glyphosate aplicado en concentraciones de $0.5,1.0,1.5$ y $2.0 \%$ a manchones de malezas en pastos de Barceloneta, Camuy, Fajardo 
y Gurabo, controló eficazmente por espacio de 140 días las gramíneas cortadera (Paspalum virgatum L.), serrillo (Sporolobus indicus (L.) R. Br.), horquetilla (Paspalum conjugatum Berg.) y la malvácea escobilla (Sida rhombifolia L.). Estas malezas también se controlaron eficazmente con el aplicador de esponja y el frotador a las concentraciones de 14.3, 20 y $33 \%$.

\section{LITERATURE CITED}

1. Cárdenas, J., Reyes, C. y Doll, J., 1974. Malezas Tropicales, Bogotá, Colombia, COMALFI.

2. Cibes, H. R., 1962. Control of harsh grasses in pasturelands, J. Agric. Univ. P. R. 46 (1): 65 .

3. — 1980. Agric. Exp. Stn. Annu. Prog. Rep. on pastures for 1976 and 1979.

4. García-Molinari, O., 1952. Grasslands and Grasses of Puerto Rico, Agric. Exp. Stn. Univ. P.R. Bull, 102.

5. González-Ibáñez, J., 1977. Control of resistant broadleaf species in Puerto Rico pastures using mixtures of 2,4-D with picloram and dicamba, J. Agric. Univ. P.R. 61 (3): 32631.

6. Vicente-Chandler, J., Abruña, F., Caro-Costas, R., Figarella, J., Silva, S. and Pearson, R. W., 1974. Intensive grassland management in the humid tropics of Puerto Rico. Agric. Exp. Stn. Univ. P.R., Bull. 233. 